\title{
Retraction Note to: Intra-articular injection in the knee of adipose derived stromal cells (stromal vascular fraction) and platelet rich plasma for osteoarthritis
}

\author{
Himanshu Bansal ${ }^{{ }^{*}}$, Kristin Comella ${ }^{2}$, Jerry Leon ${ }^{3}$, Poonam Verma ${ }^{1}$, Diwaker Agrawal ${ }^{4}$, Prasad Koka ${ }^{5}$ and \\ Thomas Ichim ${ }^{6}$
}

\section{Retraction Note to: JTransl Med (2017) 15:141}

https://doi.org/10.1186/s12967-017-1242-4

The Editor-in-Chief has retracted this article [1] due to a number of concerns that have come to light after publication. The clinical trial registry [2] for this study states that the study start date is 12 February 2012. However, documentation regarding the ethical approval provided by the corresponding author shows that the authors applied for ethics approval on 18 February 2012, and that the ethics committee approved the study on 17 September 2012. Additionally, the time stamp on Fig. $4 \mathrm{a}$ is 11 September 2012 and on Fig. 4b it's 27 February 2010, which suggests the research was conducted before ethics approval was obtained. The Editor-in-Chief therefore no longer has confidence in the reliability of the data reported in the article.

Prasad Koka agrees to this retraction. Himanshu Bansal, Kristin Comella and Thomas Ichim do not agree to this retraction. Jerry Leon, Poonam Verma and Diwaker Agrawal have not responded to any correspondence from the editor/publisher about this retraction.

\begin{abstract}
Author details
${ }^{1}$ RegennMed Research and Therapeutics LLP, Chattarpur, Delhi, India. ${ }^{2}$ US Stem Cell, Inc, Sunrise, FL, USA. ${ }^{3}$ Advance Health Institute Mayaguez, Puerto Rico, USA. ${ }^{4}$ Mercy Medical Centre, Roseburg, OR, USA. ${ }^{5}$ Department of Virology and Immunology, Hafkine Institute, Mumbai, Maharashtra 400012, India. ${ }^{6}$ Regenerative Medicine Institute, Tijuana, Mexico. ${ }^{7}$ Mother Cell Spinal Injury \& Stem Cell Research, Anupam Hospital, Second Floor, Kashipur Bypass Road, Rudrapur, Uttarakhand 263153, India.
\end{abstract}

Published online: 26 April 2021

\section{References}

1. Bansal H, Comella K, Leon J, Verma P, Agrawal D, Koka P, Ichim T. Intraarticular injection in the knee of adipose derived stromal cells (stromal vascular fraction) and platelet rich plasma for osteoarthritis. J Transl Med. 2017;15:141. https://doi.org/10.1186/s12967-017-1242-4.

2. https://www.clinicaltrials.gov/ct2/show/NCT03089762?term $=$ NCT03 089762.

\section{Publisher's Note}

Springer Nature remains neutral with regard to jurisdictional claims in published maps and institutional affiliations.

(C) The Author(s) 2021. This article is licensed under a Creative Commons Attribution 4.0 International License, which permits use, sharing, adaptation, distribution and reproduction in any medium or format, as long as you give appropriate credit to the original author(s) and the source, provide a link to the Creative Commons licence, and indicate if changes were made. The images or other third party material in this article are included in the article's Creative Commons licence, unless indicated otherwise in a credit line to the material. If material is not included in the article's Creative Commons licence and your intended use is not permitted by statutory regulation or exceeds the permitted use, you will need to obtain permission directly from the copyright holder. To view a copy of this licence, visit http://creativecommons.org/licenses/by/4.0/. The Creative Commons Public Domain Dedication waiver (http://creativecommons.org/publicdomain/zero/1.0/) applies to the data made available in this article, unless otherwise stated in a credit line to the data. 